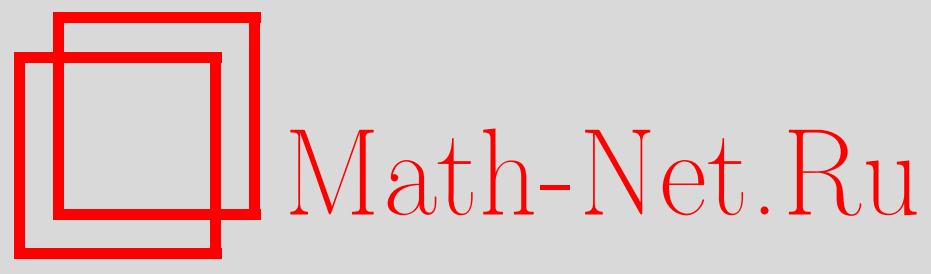

Ю. В. Прохоров, В. С. Королюк, Н. М. Зинченко, Международная конференция, посвященная 90летию со дня рождения Б. В. Гнеденко, Теория вероятн. и ее примен., 2002, том 47, выпуск 4, 821-823

DOI: https://doi.org/10.4213/tvp3789

Использование Общероссийского математического портала Math-Net.Ru подразумевает, что вы прочитали и согласны с пользовательским соглашением

http://www . mathnet.ru/rus/agreement

Параметры загрузки:

IP : 3.89.197.203

26 апреля 2023 г., 15:08:32

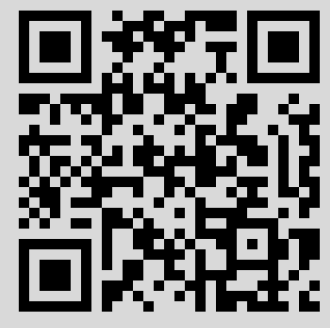




\section{МЕЖДУНАРОДНАЯ КОНФЕРЕНЦИЯ, ПОСВЯЩЕННАЯ 90-ЛЕТИЮ СО ДНЯ РОЖДЕНИЯ Б. В. ГНЕДЕНКО}

Международная конференция, посвященная 90-летию Бориса Владимировича Гнеденко, проходила в Киеве с 3 по 7 июля 2002 года. Ее организаторами были: Министерство образования и науки Украины, Киевский национальный университет им. Тараса Шевченко, кафедра теории вероятностей Московского государственного университета, Математический институт им. В.А. Стеклова Российской Академии наук, Национальный технический университет Украины (КПИ), Национальный педагогический институт им. М. Драгоманова, Львовский национальный университет им. Ивана Франко, Благотворительный фонд «Математика». Проведение конференции было поддержано Обществом математической статистики и теории вероятностей им. Бернулли. Частичная финансовая поддержка была оказана в рамках программы INTAS (проект № 9900016, исполнительный секретарь - доктор Жаак Синнаеве; проект № 990059, координатор - профессор Давид Елворси). Активное содействие в подготовке и проведении конференции оказали научные издательства «ТВіMC» (Киев) и «ТП» (Москва).

Подготовку конференции осуществлял оргкомитет, который возглавляли: ректор Киевского национального университета академик НАН Украины В. В. Скопенко (председатель), академик НАН Украины В.С. Королюк и академик Российской АН Ю.В. Прохоров. В состав оргкомитета вошли видные ученые-математики Украины и России.

Выбор места и времени проведения конференции был неслучайным: 1 января 2002 года исполнилось 90 лет со дня рождения академика Национальной академии наук Украины Бориса Владимировича Гнеденко (1912-1995), который был одним из основателей украинской школы теории вероятностей и математической статистики. Более 10 лет Гнеденко работал на Украине, и именно им начаты исследования по теории вероятностей сначала во Львове, а потом и в Киеве. С 1949 по 1960 год Борис Владимирович работал в Киеве, где создал кафедру теории вероятностей и математической статистики Киевского университета, один период времени был директором Института математики АН Украины. Среди его учеников 10 членов Национальных академий наук, в частности, академики НАН Украины В.С. Королюк, А.В. Скороход, И. Н. Коваленко, В. С. Михалевич, Ю. М. Ермольев, члены-корреспонденты НАН Украины Е. Л. Ющенко, Т. П. Марьянович, М. Й. Ядренко.

Конференция вызвала значительный интерес, о чем свидетельствует широта тематики, представительский уровень и география участников. Всего в конференции приняли участие более 200 человек (180 зарегистрированных участников) из 27 стран. Кроме украинских математиков, в ней участвовали представители Австрии, Азербайджана, Беларуси, Великобритании, Венгрии, Германии, Голландии, Грузии, Израиля, Испании, Италии, Канады, Кувейта, Литвы, Молдовы, Польши, России, Сербии, США, Уругвая, Финляндии, Франции, Хорватии, Чехии, Швеции, Японии.

Широко была представлена российская математическая школа, причем отрадно то, что наряду с москвичами - непосредственными учениками и коллегами Бориса Владимировича (с 1965 года он заведовал кафедрой теории вероятностей МГУ), в конференции приняли участие математики Санкт-Петербурга, Воронежа, Омска, Твери. 
Каждый рабочий день начинался с пленарных заседаний; всего на конференции было сделано 12 пленарных часовых докладов:

- В. С. Королюк (Украина), Н. Лимниос (Франция). «Марковские аддитивные процессы в схеме фазового укрупнения»;

- И. Н. Коваленко (Украина). «Влияние работ Б. В. Гнеденко на развитие теории надежности и теории массового обслуживания»;

- Д. Елворси (Великобритания). «Функции и формы конечной энергии»;

- М. Рёкнер (Германия). «Стохастическая динамика непрерывных систем: новые достижения»;

- А.В. Скороход (Украина, США). «Схемы проверки статистических гипотез»;

- В. Войчински (США). «Численные методы для законов Леви»;

- Ш. Чёргё (Венгрия). «Области притяжения и области частичного притяжения: Гнеденко и после него»; ности»

- Дж. Штейнбах (Германия). «Обнаружение разладки с помощью инвариант-

- М. Жанблан (Франция). «Кредитные риски»;

- Ю.Н. Линьков (Украина). «Большие уклонения в задачах проверки гипотез»;

- Д. С. Сильвестров (Швеция). «Предельные теоремы для стохастических процессов, остановленных в случайные моменты времени»;

- А. Ю. Веретенников (Россия). «Эссе на тему: Предельная теорема Б. В. Гнеденко».

Секционные (пятнадцати-, двадцати-, тридцати- и сорокаминутные) доклады были сгруппированы в 12 секций:

- предельные теоремы для независимых случайных величин (руководитель секции А. Мартикайнен);

- контроль качества, теория надежности, теория массового обслуживания (руководитель секции И. Н. Коваленко);

В. Ю. Королев);

- статистический анализ моментов разладки (руководитель секции Дж. Штейнбах);

- проблемы математического образования (руководитель секции М. Й. Ядренко);

- параметрическая статистика и проверка гипотез (руководители секции А. В. Иванов и Ю. Н. Линьков);

- предельные теоремы для случайных полей (руководители секции А. В. Булинский и Н. Н. Леоненко);

- стохастика и математическая физика (руководители секции С. Альбеверио и Ю. Г. Кондратьев);

- применение статистических методов в финансовой и актуарной математике (руководители секции Ю.С. Мишура и А.Г. Кукуш); таи);

- вероятностная теория чисел (руководители секции К. Х. Индикофер и И. Ка-

- дискретные вероятностные модели (руководитель секции А. Левитская);

- стохастический анализ (руководители секции Б. Григелионис, Д. Елворси, А. Ю. Веретенников).

Одно только перечисление названий секций свидетельствует о широте тематики конференции, удачно сочетавшей в себе развитие идей Б. В. Гнеденко и самые современные направления исследований в области теории вероятностей и ее применений.

$\mathrm{K}$ началу конференции научным издательством «ТВіМС» (руководитель О.И. Клесов) были изданы программа и тезисы докладов. Труды конференции планируется издать отдельным сборником в 2-х томах, как специальный выпуск журнала «Theory of Stochastic Processes» (ТВiMC, Киев). 
На конференции состоялись презентации монографии Д. С. Сильвестрова «Limit Theorems for Randomly Stopped Stochastic Processes» и книги «Борис Владимирович Гнеденко», составителем которой является сын ученого - профессор МГУ Д. Б. Гнеденко, а ответственным редактором - академик НАН Украины И. Н. Коваленко.

Насышенную научную программу удачно дополняла интересная культурная программа, включавшая в себя знакомство с историческими достопримечательностями Киева, событиями театрально-культурной жизни столицы Украины, фольклорным и хоровым искусством (киевская консерватория).

Приятно отметить, что, наряду с известными математиками, в конференции приняли участие молодые ученые, студенты и аспиранты из Киева, Донецка, Львова, а также молодые исследователи из других стран-участниц конференции. Это позволяет надеяться на продолжение лучших традиций украинской вероятностной школы, сохранение и дальнейшее развитие ее широких международных связей. Успешное проведение этой конференции - не только дань памяти великого ученого и педагога, но и свидетельство неразрывной преемственности поколений. В этой связи хотелось бы привести слова самого Бориса Владимировича Гнеденко, который в одной из своих последних работ писал: «Я счастлив, что на мою долю выпала почетная миссия создания теоретико-вероятностной школы в Украине. Теперь она пополнилась большим количеством моих научных внуков и правнуков; она завоевала серьезное место в жизни современной теории вероятностей. Очень важно, чтобы она росла не только в количественном отношении, но и в качественном. Очень важно, чтобы в поле зрения этой школы попадали новые области исследований и чтобы она не отрывалась от практики». 